\title{
Growing straight versus growing decumbent: soil quality and allometry in Syagrus glaucescens Becc. (Arecaceae), an endemic and threatened palm of the Espinhaço Mountains, Brazil
}

\author{
Deise Tatiane Bueno Miola ${ }^{1 *}$ and G. Wilson Fernandes ${ }^{2,3}$
}

Received: February 9, 2015. Accepted: May 11, 2015

\begin{abstract}
Syagrus glaucescens is an endemic palm found in the rupestrian grasslands of the Espinhaço Mountains in southeastern Brazil. It is highly associated with quartzitic soils and exhibits strong intra-specific morphological variation in the different areas where it occurs. Allometric traits were used to verify whether there are any significant differences in the morphological traits between populations of this species located in two distinct areas. In the region of the Serra do Cipó individuals exhibit decumbent stems whereas on the Diamantina Plateau stems are straight and perpendicular to the ground. Soil quality was related to plant morphological traits to test the hypothesis that allometric variation is influenced by soil nutritional differences. Stem shape and size differed significantly among individuals inhabiting the two different regions: individuals in Serra do Cipó were shorter and had fewer leaves compared to individuals found in the Diamantina Plateau. Water retention capacity and nutrient absorption of the soils of the two sites were markedly different. In Serra do Cipó the soils were more acid, with higher aluminum saturation and lower sand content compared to the soils in Diamantina. These traits correlated with stem shape and indicate that soil acidity and aluminum saturation influence the architecture of S. glaucescens.
\end{abstract}

Keywords: aluminum saturation, Diamantina, phenotypic variability, rupestrian grasslands, Serra do Cipó, soil-plant relationships

\section{Introduction}

Phenotypical variation in plant morphology may result from genetic differences among individuals and/or from the effects of environmental factors such as light, rainfall and soil quality (e.g., Archibald \& Bond 2003; Ellison et al. 2004). Plant allometry, the study of size-correlated variations in organic form and process (Niklas 1994), is a powerful tool in understanding not only how abiotic factors cause these variations but also to investigate adaptive differences among species, competitive interactions, forest structure and dynamics, and plant life history (e.g., Niklas 1993; 2006; Weiner \& Fishman 1994; Sposito \& Santos 2001; Kimura \& Simbolon 2002; Poorter et al. 2012).

Allometric studies in the Neotropics have been focused primarily on rainforest species (e.g., King 1996; Fontes 1999; Alves \& Santos 2002; Kimura \& Simbolon 2002; Osunkoya et al. 2007; Calvo-Alvarado et al. 2008; Rosseto et al. 2013) in an attempt to link the allometry of supporting and photosynthesizing structures with different life histories and light assimilation strategies (see also Lüttge et al. 2007).
In open vegetation, however, where light is not a limiting factor, such as in the Cerrado (savanna), shortage on water and nutrient supply, and escape from fire and herbivores may represent the most important factors selecting plant allometric variation (Archibald \& Bond 2003).

The rupestrian grasslands are the most endangered and threatened physiognomy of the Brazilian Cerrado (Fernandes et al. 2014). The rupestrian grassland ecosystem is under the influence of seasonal climate with rainy summers and dry winters, is mostly established in quartzite-derived soils above $900 \mathrm{~m}$ a.s.l.. The vegetation is strongly influenced by the substrate, climate and topography, with resulting high environmental heterogeneity (Carvalho et al. 2012; 2014). Sclerophyllous scattered shrubs and short trees form an open and poor developed canopy among the well-developed herbaceous layer. Water deficit, poor and shallow soils, and fires are important factors driving plant distribution and structure (Burman 1991; Giulietti et al. 1997).

Syagrus glaucescens (Arecaceae), popularly known as "coquinho-da-pedra", is an endemic palm tree of the rupestrian grasslands of the Espinhaço mountains. Casual

\footnotetext{
${ }^{1}$ Faculdade de Pará de Minas, Ricardo Marinho 110, 35660-398, Pará de Minas, MG, Brazil

${ }^{2}$ Departamento de Biologia Geral, Instituto de Ciências Biológicas, Universidade Federal de Minas Gerais, 31270-901, Belo Horizonte, MG, Brazil

${ }^{3}$ Department of Biology, Stanford University, Stanford CA 94305 USA

* Corresponding author: deisemiola@gmail.com
} 
observations indicate differences in the morphology of individuals in two localities of its native range. In Serra do Cipó, the stem is strongly decumbent whereas in the Diamantina plateau its stems are mostly straight and perpendicular to the soil. Observations also indicate that while in Serra do Cipó S. glaucescens is found exclusively on rocky outcrops, in Diamantina it can be also found in quartzite-derived soils with well-developed vegetation. Here, we investigated the allometric variation in the two phenotypes of S. glaucescens and tested the hypothesis that soil nutritional traits influence such variation. We used a comparative approach to answer the following questions: (1) do stem length and shape of individuals of S. glaucescens vary between the two regions?; (2) are there differences in soil nutritional quality between the regions?; and (3) if so, do these differences account for allometric variation?

\section{Material and Methods}

\section{Study area}

This study was conducted in two regions of the Espinhaço mountain range, in Minas Gerais, Brazil. In Serra do Cipó the study was performed at the "Reserva Particular Vellozia” and its surroundings ( $43^{\circ} 33^{\prime} \mathrm{W}, 19^{\circ} 20^{\prime} \mathrm{S}$ to $43^{\circ} 39^{\prime} \mathrm{W}$, $19^{\circ} 12^{\prime}$ S), in the Area de Proteção Morro da Pedreira, in the municipality of Santana do Riacho. A wider studied area was examined in Diamantina plateau, including the city of Diamantina and the Parque Estadual do Biribiri ( $43^{\circ} 36^{\prime} \mathrm{W}$, $18^{\circ} 18^{\prime} \mathrm{S}$ to $\left.43^{\circ} 45^{\prime} \mathrm{W}, 17^{\circ} 54^{\prime} \mathrm{S}\right)$. Both regions are dominated by rupestrian grassland vegetation and were selected due to the high abundance of Syagrus glaucescens Becc. and easy access. Distance between the study sites is about $125 \mathrm{~km}$.

An herbaceous layer characterizes the landscape of the rupestrian grasslands where rocky outcrops, epilithic and woody species sparsely occurs creating vegetation islands. The climate is latitude - and altitude-dependent and is classified as Cwb following Köppen, with dry winters and rainy summers and mean annual temperature varies from 17.4 to $19.8^{\circ} \mathrm{C}$ (Madeira \& Fernandes 1999). Soils are shallow, acid, nutrient-poor, and as a result of high sand content, they are subjected to erosion and have low water retention capacity (Negreiros et al. 2009; Carvalho et al. 2012; Le Stradic et al. 2014).

\section{Studied species}

Syagrus glaucescens is a small palm with distribution strongly associated with quartzite outcrops that occurs in the rupestrian grasslands from Serra do Cipó to Diamantina (Miola et al. 2011). It was included in the list of threatened species of the International Union for Conservation of Nature and Natural Resources (Vulnerable category) as a result of its small distributional area and high destruction of its native habitat (Noblick 1998). Despite this fact, the few studies on S. glaucescens are restricted the phenology (Miola et al. 2010; Belo et al. 2013) and spatial distribution (Miola et al. 2011). Miola et al. (2010) also observed resistance and increased flowering after fire.

Adults of Syagrus glaucescens might reach up to four meters high and are usually found aggregated in small populations. The stem may be straight or decumbent. Glassman (1987) described two closely related Syagrus Mart. species in the region and argued that morphological differences in plant height and leaflet number were the main criteria for splitting them. On the other hand, their distribution patterns were also different: while $S$. duartei Glassman was restricted to the quartzitic outcrops above $1300 \mathrm{~m}$ in Serra do Cipó S. glaucescens was found in northern Diamantina region, always at lower elevations. Conversely, Marcato \& Pirani (2001) argued that splitting Syagrus into two species was complicated in the field due to overlap in morphological traits. Therefore, we adopted the criteria established by Marcato \& Pirani (2001), who merged the two species into $S$. glaucescens, to address our questions.

\section{Allometric analysis}

To examine differences in allometry between the two phenotypes (Serra do Cipó, and Diamantina), 42 adults (individuals with the presence of reproductive structures) in each region were randomly selected and tagged. Individuals were randomly selected during random walks, always considering a minimum distance of $20 \mathrm{~m}$ between marked plants. Stem length, height, and diameter, and total number of leaves were recorded for each individual to indicate the allometric parameters. Stem length was defined as the distance between stem base to the tip of the leaf apex whereas stem height was the vertical distance from ground level to the tip leaf apex. When the plant has the habit decumbent, length tends to be larger than the height, so the stem length/ height ratio $(\mathrm{L} / \mathrm{H})$ was used as a measure of stem shape. The Kolmogorov-Smirnov test was used to examine data normality. We compared the $\mathrm{L} / \mathrm{H}$ ratio using Mann-Whitney test, as the data were not normally distributed. Differences in stem length, height and diameter, and total leaf number between the two phenotypes were evaluated using a t-test Data were log-transformed to better fit the linear regressions on the measured variables (Niklas 2004).

\section{Soil analysis}

To characterize the soils where the two phenotypes of Syagrus glaucescens were growing, 15 mixed soil samples from each population were obtained $(\mathrm{n}=30)$. Mixed sample (10 soil samples collected beneath each palm individual) consisted of soil collected from 0 to $15 \mathrm{~cm}$ depth. The procedures for mixed samples followed Dick et al. (1996). Each sample was dried at room temperature under shade, homogenized, and sent to the Soil Department of the Federal 
University of Viçosa for analysis. Soil granulometric analyzes (fine sand, coarse sand, silt, clay) were performed following EMBRAPA (1997).

For variables with normal distribution or log-transformed, differences in soil properties between areas were analyzed through a T-test, whereas Mann-Whitney test was applied for variables with non-parametric distribution. Soil traits that statistically differed between the two areas were correlated with plant traits using Pearson's correlation.

\section{Results}

\section{Allometric variation}

A significant difference in stem length, height, and total leaf number were observed between the two phenotypes of Syagrus glaucescens (Tab. 1). The phenotype found in Diamantina had consistently longer stems (ca. $21 \%$ ), were taller (35\%; Fig. 1) and had more leaves (19\%) than the phenotype found in Serra do Cipó. Stem shape also differed between the two phenotypes $(t=2507, \mathrm{P}<0.001)$. In Diamantina stems were straight and perpendicular to the soil, whereas in Serra do Cipó stems were tortuous and decumbent. The height and length measurements of stems were significantly correlated in spite of the morphological differences found between the two phenotypes (Fig. 2). Stem diameter did not vary with stem length or height in any of the phenotypes (Tab. 2). Nevertheless, stem height and diameter were positively correlated $(\mathrm{r}=0.562, \mathrm{P}=0.009$; Fig. 3). L/H ratio was negatively correlated to stem diameter $(\mathrm{r}=-0.569, \mathrm{P}=0.008)$ and height $(\mathrm{r}=-0.650, \mathrm{P}=0.001$; Fig. 3), indicating that stem height and diameter decreased as the shoot became more decumbent.

Total leaf number (an estimation of crown volume) was also positively correlated with stem height $(\mathrm{r}=0.60$, $\mathrm{P}=0.005)$, length $(\mathrm{r}=0.886, \mathrm{P}<0.001)$, and with stem diameter $(r=0.815, \mathrm{P}<0.001$; Fig. 3$)$. Otherwise, total leaf number correlated negatively with the $\mathrm{L} / \mathrm{H}$ ratio $(\mathrm{r}=-0.614$, $\mathrm{P}=0.004$ ). Albeit a statistically significant correlation between total leaf number and stem height was found, there were no significant differences between the two phenotypes $(t=1.40, \mathrm{P}$ $=0.276$ ). Conversely, the linear regression between stem length and total leaf number of S. glaucescens differed statistically between the two populations studied ( $\mathrm{t}=3.8711, \mathrm{P}<0.001$; Fig. 4 ).

\section{Soil nutritional status}

Soils colonized by Syagrus glaucescens were very similar in organic matter and macronutrient content in the two regions (Tab. 3). However, significant differences between the two areas were found in remanescent phosphorous, $\mathrm{Al}$ saturation, $\mathrm{pH}$, and soil granulometry (Tab. 3), supporting the contention that water retention capacity and nutrient absorption is different in the soils of the two regions. Soils in Serra do Cipó are more acidic, alic with higher Al content compared to soils in Diamantina.

Table 1. Summary statistics (mean $\pm \mathrm{SD}$ ) of the two phenotypes of Syagrus glaucescens $(\mathrm{n}=42),{ }^{*} \mathrm{P}<0,001 ;{ }^{* *} \mathrm{P}<0,005$; ${ }^{\text {ns }}=$ non significant).

\begin{tabular}{cccc}
\hline Plant traits & Diamantina & Serra do Cipó & t value \\
\hline Height $(\mathrm{cm})$ & $176.61 \pm 59.68$ & $114.26 \pm 42.89$ & $5.442^{*}$ \\
Length $(\mathrm{cm})$ & $178.71 \pm 60.36$ & $141.09 \pm 41.94$ \\
Diameter $(\mathrm{cm})$ & $53.14 \pm 15.42$ & $50.16 \pm 20.31$ \\
Total leaf number (unit) & $8.97 \pm 2.00$ & $7.30 \pm 1.47$ & $1.339^{\text {ns }}$ \\
\hline
\end{tabular}

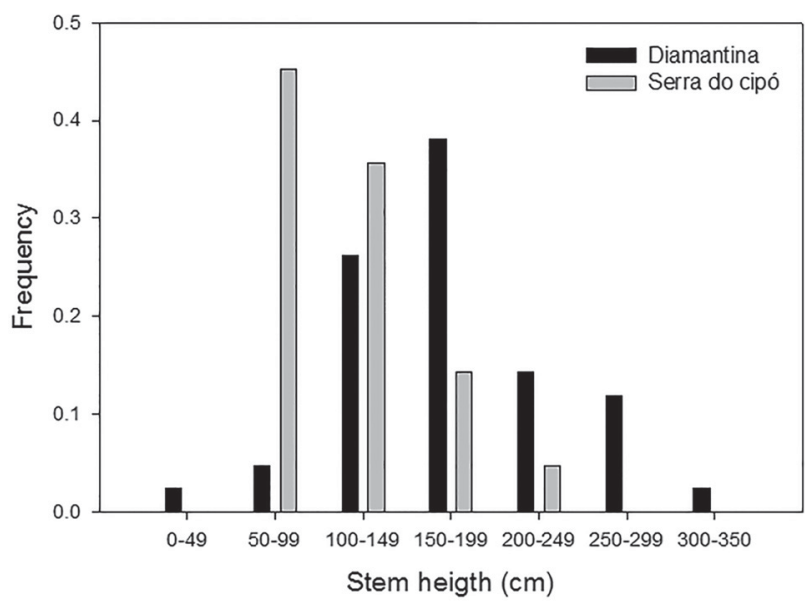

Figure 1. Stem height classes of Syagrus glaucescens in both studied areas.

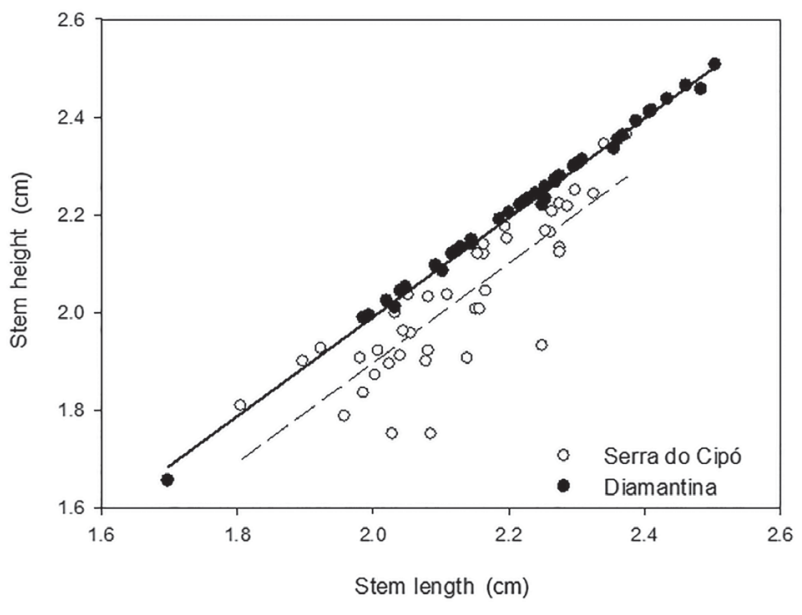

Figure 2. Linear regressions between stem length and height in Diamantina $\left(\mathrm{F}=8792.725 ; \mathrm{P}<0.001 ; \mathrm{r}^{2}=0.9955 ; \mathrm{y}=-0.0445+1.0174 . \mathrm{x}\right)$ and in Serra do Cipó $\left(\mathrm{F}=103.2182 ; \mathrm{P}<0.001 ; \mathrm{R}^{2}=0.7207 ; \mathrm{y}=0.6983+0.7057 . \mathrm{x}\right)$. 
Table 2. Summary of linear regression between stem diameter, stem length and height $(n=42)$. (Confidence interval $=95 \%) . \mathrm{R}^{2}=$ determination coefficient, $\mathrm{r}=$ regression coefficient.

Diamantina

Diameter $\times$ Height

Diameter $\times$ Length

Serra do Cipó

Diameter $\times$ Height

Diameter $\times$ Length
0.0154

0.0109

0.0335

0.0040
0.171

0.141

0.155

0.0447
0.627

0.440

1.388

0.163
0.511

0.433

0.246

0.689
Diameter

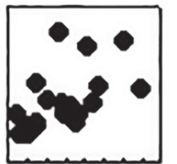

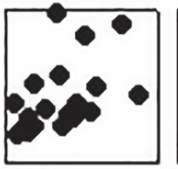

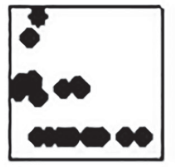

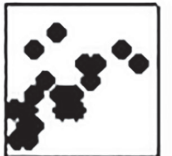

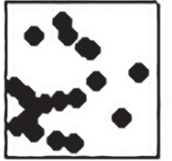

$\lim _{0} \infty$

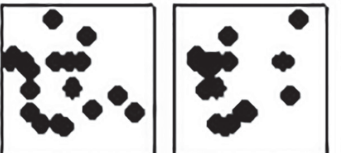

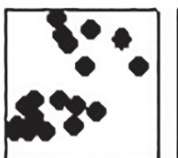
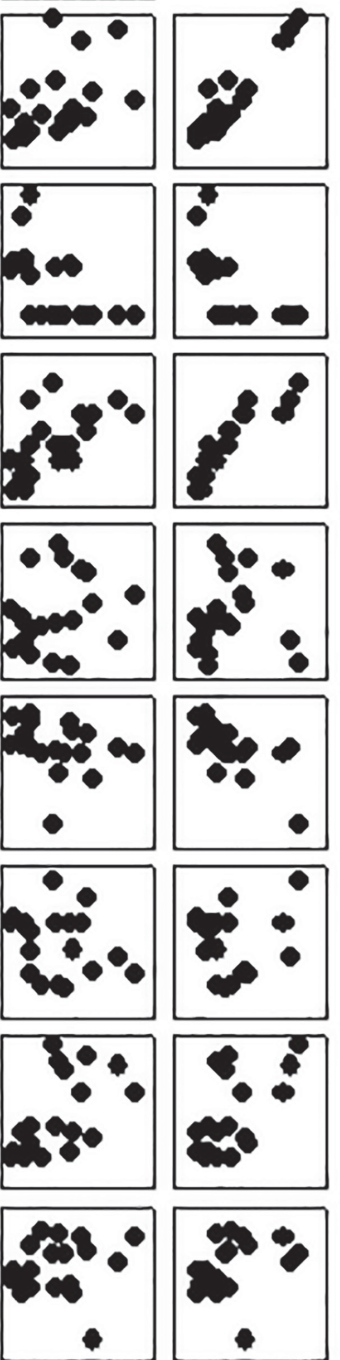
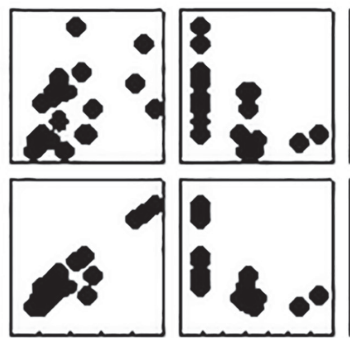

Length
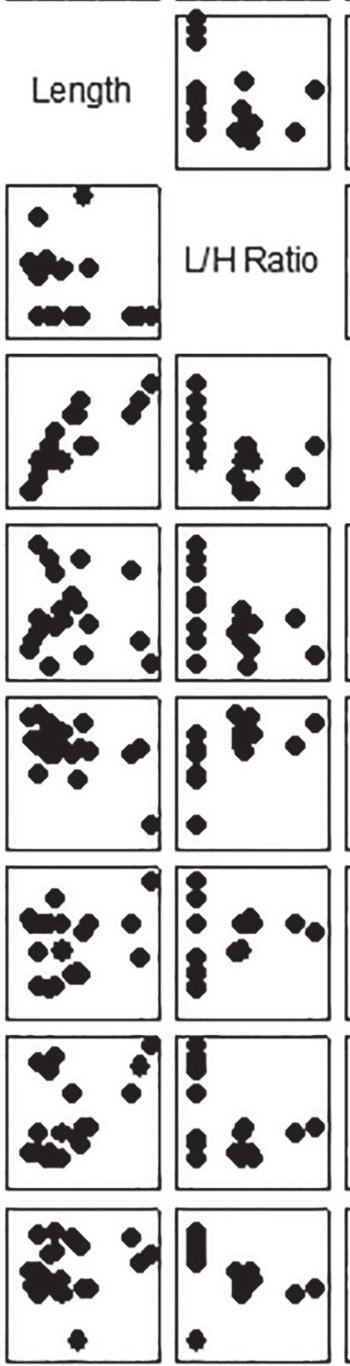
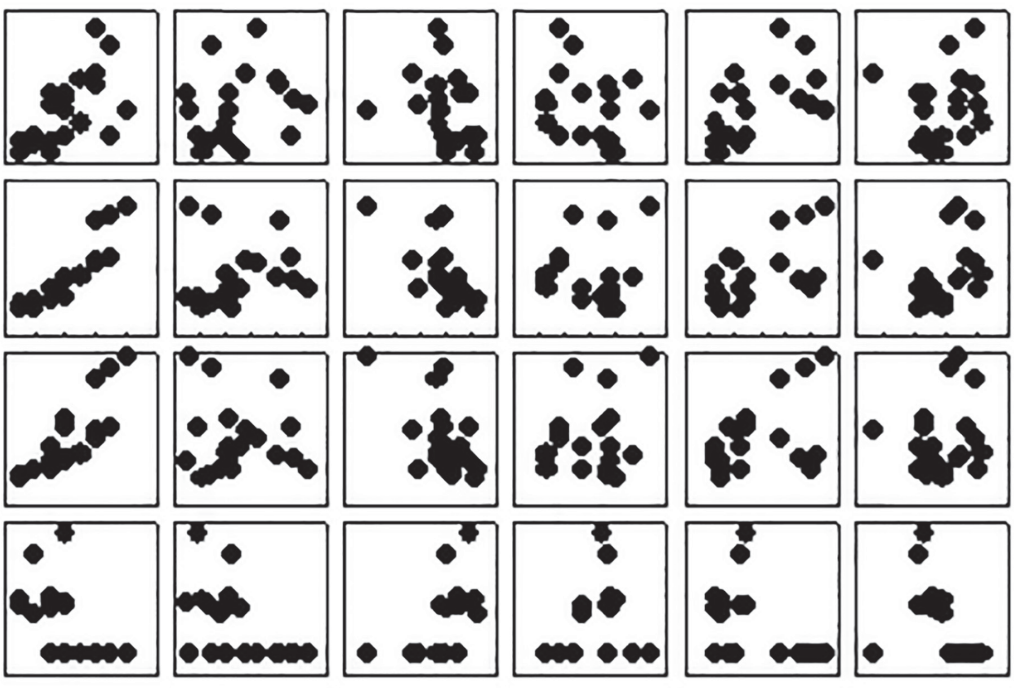

Leaves
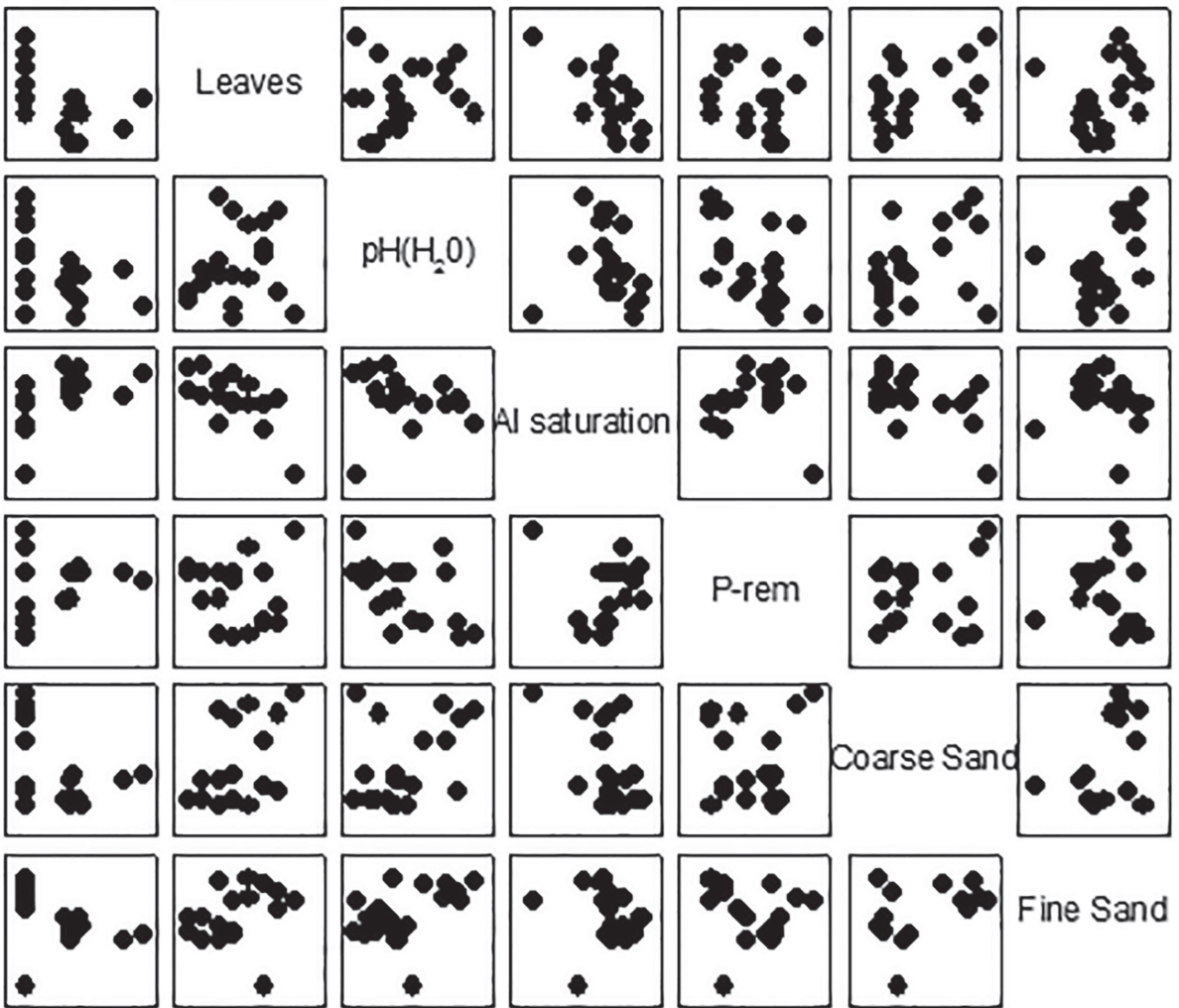

P-rem

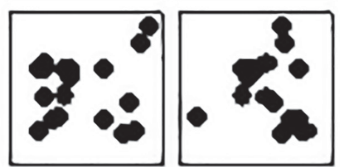

Figure 3. Pearson correlation between soil and plant traits $(\mathrm{n}=20)$. 


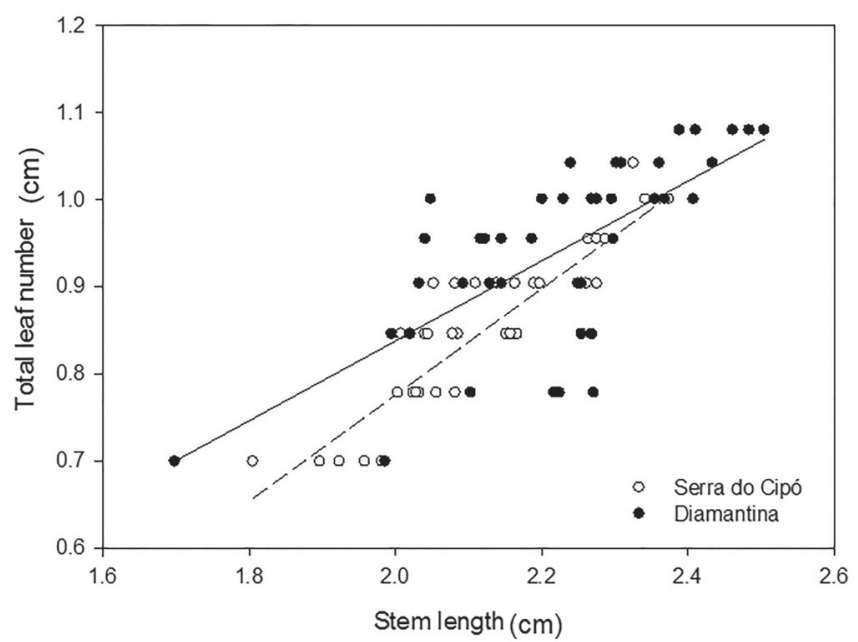

Figure 4. Linear regression between stem length and total leaf number of Syagrus glaucescens in Diamantina $\left(\mathrm{F}_{1,40}=37.905 ; \mathrm{P}<0.001 ; \mathrm{r}^{2}=0.4866 ; \mathrm{y}=-0.0777+\right.$ 0.4579.x $)$ and Serra do Cipó $\left(\mathrm{F}_{1,40}=167.245 ; \mathrm{P}<0.001 ; \mathrm{r}^{2}=0.8070 ; \mathrm{y}=-0.4426+0.6091 . \mathrm{x}\right)$.

Table 3. Chemical and textural traits of soils in which S. glaucescens was found. Means $( \pm \mathrm{SD} ; \mathrm{n}=10)$ for both studied areas are followed by their respective $\mathrm{P}$ and $\mathrm{t}$ values $(\alpha<0.05)$. Variables with asterisk represent statistically different means between the two phenotypes.

\begin{tabular}{|c|c|c|c|c|c|}
\hline Parameter & Diamantina & Serra do Cipó & Statistical Test & $\mathrm{P}$ & $\mathrm{t}$ \\
\hline $\mathrm{pH}\left(\mathrm{H}_{2} \mathrm{O}\right)^{*}$ & $4.46 \pm 0.30$ & $4.14 \pm 0.14$ & $\mathrm{t}$ & 0.008 & 2.978 \\
\hline $\mathrm{P}\left(\mathrm{mg} / \mathrm{dm}^{3}\right)$ & $1.58 \pm 0.80$ & $1.66 \pm 0.37$ & M-W & 0.493 & 95.500 \\
\hline $\mathrm{K}\left(\mathrm{mg} / \mathrm{dm}^{3}\right)$ & $39.00 \pm 17.76$ & $51.00 \pm 19.48$ & $\mathrm{t}$ & 0.167 & -1.439 \\
\hline $\mathrm{Ca}^{2+}\left(\mathrm{cmol}_{\mathrm{c}} / \mathrm{dm}^{3}\right)$ & $0.02 \pm 0.02$ & $0.002 \pm 0.006$ & $\mathrm{M}-\mathrm{W}$ & 0.101 & 122.000 \\
\hline $\mathrm{Mg}^{2+}\left(\mathrm{cmol}_{\mathrm{c}} / \mathrm{dm}^{3}\right)$ & $0.093 \pm 0.18$ & $0.074 \pm 0.02$ & $\mathrm{M}-\mathrm{W}$ & 0.068 & 80.500 \\
\hline $\mathrm{Al}^{3+}\left(\mathrm{cmol}_{\mathrm{c}} / \mathrm{dm}^{3}\right)^{*}$ & $1.28 \pm 0.56$ & $2.586 \pm 0.386$ & $\mathrm{t}$ & $<0.001$ & -6.076 \\
\hline $\mathrm{H}+\mathrm{Al}\left(\mathrm{cmol}_{\mathrm{c}} / \mathrm{dm}^{3}\right)$ & $10.19 \pm 3.67$ & $11.30 \pm 2.38$ & $\mathrm{t}$ & 0.433 & -0.802 \\
\hline $\mathrm{BS}\left(\mathrm{cmol}_{\mathrm{c}} / \mathrm{dm}^{3}\right)$ & $0.22 \pm 0.17$ & $0.19 \pm 0.08$ & $\mathrm{t}$ & 0.985 & 0.0193 \\
\hline $\mathrm{CEC}_{\text {effective }}\left(\mathrm{cmol}_{\mathrm{c}} / \mathrm{dm}^{3}\right)$ & $1.53 \pm 0.67$ & $2.810 \pm 0.396$ & $\mathrm{t}$ & 0.440 & -0.789 \\
\hline $\mathrm{CEC}_{\mathrm{pH} 7.0}\left(\mathrm{cmol}_{\mathrm{c}} / \mathrm{dm}^{3}\right)$ & $10.40 \pm 3.83$ & $11.51 \pm 2.19$ & $\mathrm{t}$ & 0.440 & -0.789 \\
\hline Bases saturation (\%) & $1.94 \pm 0.72$ & $1.80 \pm 0.82$ & $\mathrm{t}$ & 0.692 & 0.434 \\
\hline $\mathrm{Al}$ saturation $(\%)^{*}$ & $86.72 \pm 4.95$ & $92.75 \pm 2.57$ & $\mathrm{M}-\mathrm{W}$ & 0.001 & 61.000 \\
\hline Organic matter (dag/kg) & $5.81 \pm 2.04$ & $6.51 \pm 1.88$ & $\mathrm{t}$ & 0.434 & -0.799 \\
\hline P remanescent $(\mathrm{mg} / \mathrm{L})^{*}$ & $25.29 \pm 15.23$ & $35.16 \pm 4.78$ & $\mathrm{M}-\mathrm{W}$ & 0.049 & 78.500 \\
\hline Coarse sand $(\%)^{*}$ & $23.900 \pm 7.866$ & $13.600 \pm 2.547$ & $\mathrm{t}$ & $<0.001$ & 3.939 \\
\hline Fine sand $(\%)^{*}$ & $54.000 \pm 10.477$ & $44.600 \pm 2.875$ & $\mathrm{M}-\mathrm{W}$ & 0.003 & 145.000 \\
\hline Silt $(\%)^{*}$ & $11.600 \pm 6.004$ & $31.000 \pm 1.491$ & $\mathrm{t}$ & $<0.001$ & -9.917 \\
\hline Clay $(\%)$ & $10.500 \pm 8.695$ & $10.800 \pm 1.687$ & $\mathrm{M}-\mathrm{W}$ & 0.126 & 85.000 \\
\hline
\end{tabular}

A negative correlation was found between $\mathrm{pH}$ and $\mathrm{L} / \mathrm{H}$ $(\mathrm{r}=-0.528, \mathrm{P}=0.016)$, whereas $\mathrm{Al}$ saturation correlated positively with $\mathrm{L} / \mathrm{H}(\mathrm{r}=0.540, \mathrm{P}=0.014)$, strengthening the hypothesis that soil acidity and $\mathrm{Al}$ saturation influence the morphogenetic process of $S$. glaucescens stem growth in both areas (Tab. 3). With regards to soil granulometry in which Syagrus glaucescens was found, 100\% of the samples in Serra do Cipó can be classified as sandy loams, while in Diamantina soils varied widely $(11.1 \%$ sands, $11.1 \%$ silt loam, 33.3\% sandy loams and 44.5\% loamy sands).

Following the Minas Gerais State Agronomic Soil Classification (Alvares et al. 1999), the soils colonized by Syagrus glaucescens were acidic and deficient in most sampled macronutrients (Tab. 3). Organic matter levels, however, were within the standards for the state of Minas Gerais. In respect to $\mathrm{Al}$ toxicity, a trend for high to very high $\mathrm{Al}^{3+}$ levels and $\mathrm{Al}$ saturation was observed.

\section{Discussion}

The stem shape was significantly different in the two phenotypes as well as were soil characteristics in sites where they occurred. Morphological differences (stem shape, height, length and total leaf number) were strongly correlated with exchangeable $\mathrm{Al}$ and $\mathrm{Al}$ saturation in the soil. The aluminum was the factor that most correlated with morphological variation in Syagrus glaucescens. Aluminum is known to 
influence soil pH (see Goodland \& Pollard 1973; Malavolta \& Kliemann 1985). Aluminum toxicity is an important factor constraining Cerrado plant development; it tends to increase nutrient deficiency (Goodland \& Ferri 1979) and reduce the size of the plants (Oliveira-Filho \& Ratter 2002). The high concentration of aluminum result in inhibition of root growth (Delhaize \& Ryan 1995), which can affect the stability of the stem. In general, root elongation is hampered through reduced mitotic activity induced by $\mathrm{Al}$, with subsequent increase in susceptibility to drought (Jones \& Kochian 1995). It is likely that higher $\mathrm{Al}$ saturation and low $\mathrm{pH}$ values (a consequence of high $\mathrm{Al}$ availability; Motta et al. 2002) in Serra do Cipó account for the decumbent stem shape of $S$. glaucescens. In Diamantina, low $\mathrm{Al}$ saturation and higher $\mathrm{pH}$ values were lower compared to Serra do Cipó and perhaps did not impair plant development allowing the production of higher stems with larger crown volume (as suggested by total leaf number). The low soil quality to which Syagrus glaucescens is associated in both areas is the result of high leaching of weathered material (Benites et al. 2003; 2007). Organic matter levels in the soils can considered satisfactory according to the agronomic classification of Alvares et al. (1999). Low soil pH results in decreased microbial activity, reducing the ratio of organic matter decomposition (Lopes 1984). In addition, plant sclerophylly, a common feature of the rupestrian grassland's flora (Negreiros et al. 2014), should also account for high levels of organic matter since microbial degradation is reduced (Carvalho et al. 2012).

Significant differences in water retention capacity were observed between soils in the two areas. The soils of Diamantina were richer in sand compared to soils in Serra do Cipó. Nevertheless, soils in Diamantina were relatively deeper, allowing higher root development that provides higher mechanical stability, which should allow the production of a higher stem in relation to the ground. In Serra do Cipó, all Syagrus glaucescens plants were found on rocky outcrops, where soil depth was rarely over $10 \mathrm{~cm}$. It is likely that stem shape of S. glaucescens in Serra do Cipó could provide lesser mechanical stability as a consequence of poor root development. However, future experimental work is needed to support these hypotheses.

\section{Allometric relations and models of mechanic stability in Syagrus glaucescens}

Three models of mechanical stability were proposed to describe the allometric relationship between stem height and diameter (Niklas 1994). The elastic similarity model states that the diameter (D) varies in the proportion of $3 / 2$ of stem height $(\mathrm{H})$, according to the relation $\mathrm{D} \alpha \mathrm{H}^{3 / 2}$ (MacMahon 1973). According to the stress similarity model, the stem size at any point varies in a way that the bending stress remains constant along the stem following the relation $\mathrm{D} \propto \mathrm{H}^{2}$ (Niklas 1994). Finally, the geometric similarity model predicts that structures of different sizes retain isometric proportions, so that increases in height causes a directly proportional increase in diameter, following the relation $\mathrm{D} \alpha \mathrm{H}^{1}$ (Niklas 1994). Otherwise, these relationships are different in distinct ecological groups and in different taxa (Alves et al. 2004). All the eight species studied by O'Brien et al. (1995) at a semi-deciduous forest in Panama showed values close to the elastic similarity model. Cecropia species from Amazonian and from southeastern Brazil in open or disturbed habitats were all close to the geometric similarity model (Sposito \& Santos 2001). For other pioneer species, the values did not fit any of the predicted mechanical stability models (Alvarez-Buylla \& Martinez-Ramos 1992; Santos 2000), as it was also found for Euterpe edulis, an endemic palm of Brazilian Atlantic Forest (Alves et al. 2004). For all mentioned species, strong allometric relations between stem height and diameter were found, making Syagrus glaucescens an exception to the provided models along with Metroxylon sagu (Kjaer et al. 2004). The study by Goodman et al. (2013) also found a weak height-diameter relationships to palm species in Amazon. Astrocaryum and Attalea, for example, have a wide range of heights across a broad range of diameters with very little relationship between the two.

Niklas (1993) argued that palms tend to match the geometric stability model, but the regressions between stem height and diameter of Syagrus glaucescens were notsignificant for both phenotypes. Hence, linear regression coefficients values (an indication of stem height variation in response to diameter) did not match the values predicted by any of the three stability models. Our data on the allometry in S. glaucescens corroborates the study by Schatz et al. (1985) for tropical palms, indicating that a direct relationship between stem height and diameter may not always exist; i.e., it can change in shape during stem growth (Alves et al. 2004). This fact was observed in palm Euterpe precatoria that showed geometric similarity in individuals under one meter, whereas palms above this value did not adjust to any mechanical model (Avalos \& Otárola 2010).

Although the allometric relationships between stem height and leaf number were significant, no differences between the two phenotypes were observed. A strong difference in the slope of the regression between total leaf number and stem length between the two phenotypes was observed, indicating that although an increase in stem length resulted in higher leaf production in both areas, in Diamantina fewer leaves were produced with an increasing in stem length compared to Serra do Cipó.

\section{Morphological variation: genetic or environmental basis?}

Reports on remarkable changes in plant anatomy, morphology and physiology in response to biotic and abiotic factors are widespread in the literature (Lortie \& Aarssen 1996), including many Cerrado species (e.g., Marques et al. 2000; Cardoso \& Lomônaco 2003; Rocha-Filho \& Lomônaco 2006; Negreiros et al. 2014). Variation in plant traits 
may be under the control of genetic differences with the formation of ecotypes (Cordell et al. 1998; Kjaer et al. 2004) or may be the net result production of different phenotypes in response to environmental conditions where the plants are growing with no genetic basis (phenotypic variability, Via et al. 1995; Agrawal 2001).

Metrosideros polymorpha (Myrtaceae) is a high polymorphic tree in Hawaii, whose traits are chiefly determined by altitude and soil nutritional status (Cordell et al. 1998). Plant height decreased and leaf pubescence increased with increasing elevation, where soils had low water retention capacity, low nitrogen levels and high daily temperature fluctuation. In contrast, plants growing at lower elevation have longer stems whereas anatomical leaf traits related to water economy decrease as a function of soil higher water retention capacity and higher $\mathrm{N}$ and organic matter availability (Cordell et al. 1998). Individuals of Acacia karroo occurring in forest, savanna and arid-shrublands in South Africa present remarkable differences in stem and branching architecture (Archibald \& Bond 2003). Trees in savannas present an elongated growth form with small canopy and leaf areas and tall, thin, unbranched trunks. On the other hand, trees in arid areas showed opposite trends with wider canopies, and increased lateral branching. Archibald \& Bond (2003) argued that these differences could be explained by the differential selective pressures imposed by each of the environments inhabited by this species. In savannas there is a great pressure for rapid vertical growth to escape fires, while in arid areas a defensive, lateral growth form is selected for. Plasticity in allocation can be understood as a change in a plant's allometric trajectory in response to the environment (Weiner 2004).

Though we argue that granulometry and soil nutritional differences may influence Syagrus glaucescens morphological traits, the morphogenetic effects caused by wind should not be discarded (Cordero et al. 2007). Furthermore, genetic-based differences may also play an important role. While Glassman (1987) validated two Syagrus species in the Espinhaço mountains, Marcato \& Pirani (2001) recognized S. glaucescens as a single species based in morphology rather than on molecular data. According to Glassman (1987), S. glaucescens and $S$. duartei are similar species being only distinguishable by differences in total height (S. glaucescens being shorter than S. duartei), rachillae number (15-17 for S. glaucescens and 5-8 for $S$. duartei), pinnae number (38-40 for S. glaucescens and 60-64 for S. duartei). In addition, Glassman (1987) also stated the two species have very different spatial distribution: S. duartei is endemic of Serra do Cipó whereas S. glaucescens occurs not only in Serra do Cipó but also in Diamantina. Although Marcato \& Pirani (2001) have fused the two species in S. glaucescens by overlapping morphological characters observed, our data support the evidence of two distinct species or at least ecotypes; therefore calling for molecular studies in order to evaluate the genome of these two ecotypes or species.

\section{Acknowledgements}

We thank John Du Vall Hay, Ana Clara Mourão Moura, Jean Carlos Santos, Yumi Oki, Daniel Negreiros, Tatiana Garabini Cornelissen and Fernando Augusto de Oliveira e Silveira for comments on early drafts of the manuscript. Henriqueta Vasconcelos Lemos Correia, Gilberto Nepomuceno Salvador, and Alfredo Alberto Soares Delpino provided field assistance. This study was supported by FAPEMIG, CNPq, Planta Tecnologia Ambiental and Reserva Vellozia. This study was in partial fulfillment for the degree of Master of Science in Ecology, Conservation and Management of Wildlife at the Universidade Federal de Minas Gerais of Deise Tatiane Bueno Miola.

\section{References}

Agrawal AA. 2001. Phenotypic plasticity in the interactions and evolution of species. Science 294: 321-326.

Alvares VHV, Novais RF, Barros NF, Cantarutti RB, Lopes AS. 1999. Interpretação dos resultados das análises de solos. In: Ribeiro AC, Guimarães PTG, Alvares VAV. (eds.) Recomendações para o uso de corretivos e fertilizantes em Minas Gerais. Viçosa, CFSEMG. p. 93-97.

Alvarez-Buylla ER, Martinez-Ramos M. 1992. Demography and allometry of Cecropia obtusifolia, a neotropical pioneer tree - an evaluation of the climax pioneer paradigm for tropical forests. Journal of Ecology 80: 275-290.

Alves LF, Martins FR, Santos FAM. 2004. Allometry of a neotropical palm, Euterpe edulis Mart. Acta Botanica Brasilica 18: 369-374.

Alves LF, Santos FAM. 2002. Tree allometry and crown shape of four tree species in Atlantic rain forest, South-East Brazil. Journal of Tropical Ecology 18: 245-260.

Archibald S, Bond WJ. 2003. Growing tall vs. growing wide tree architecture and allometry of Acacia karroo in forest, savanna, and arid environments. Oikos 102: 3-14.

Avalos G, Otárola MF. 2010. Allometry and stilt root structure of the neotropical palm Euterpe precatória (Arecaceae) across sites and successional stages. American Journal of Botany 97: 388-394.

Belo RM, Negreiros D, Fernandes GW, Silveira FAO, Ranieri BD, Morellato PC. 2013. Fenologia reprodutiva e vegetativa de arbustos endêmicos de campo rupestre na Serra do Cipó, Sudeste do Brasil. Rodriguésia 64: 817-828.

Benites VM, Caiafa NA, Mendonça ES, Schaefer CE, Ker JC. 2003. Solos e vegetação nos complexos rupestres de altitude da Mantiqueira e do Espinhaço. Floresta e ambiente 10: 76-85.

Benites VM, Schaefer CEGR, Simas FNB, Santos HG. 2007. Soils associated with rock outcrops in the Brazilian mountain ranges Mantiqueira and Espinhaço. 2007. Revista Brasileira de Botânica 30: 569-577.

Burman A. 1991. Saving Brazil's savannas. New Scientist 1758: 30-34.

Calvo-Alvarado JC, McDowell NG, Waring RH. 2008. Allometric relationships predicting foliar biomass and leaf area: sapwood area ratio from tree height in five Costa Rican rain forest species. Tree Physiology 28: 1601-1608.

Cardoso GL, Lomônaco C. 2003. Variações fenotípicas e potencial plástico de Eugenia calycina Cambess (Myrtaceae) em uma área de transição cerrado-vereda. Revista Brasileira de Botânica 26:131-140.

Carvalho F, Godoy EL, Lisboa FJG, et al. 2014. Relationship between physical and chemical soil attributes and plant species diversity in tropical mountain ecosystems from Brazil. Journal of Mountain Science 11: 875-883.

Carvalho F, Souza FA, Carrenho R, Moreira FMS, Jesus EC, Fernandes GW. 2012. The mosaic of habitats in the high-altitude Brazilian rupestrian fields is a hotspot for arbuscular mycorrhizal fungi. Applied Soil Ecology 52: 9-19. 
Cordell S, Goldstein G, Mueller-Dombois D, Webb D, Vitousek PM. 1998. Physiological and morphological variation in Metrosideros polymorpha, a dominant Hawaiian tree species, along an altitudinal gradient: the role of phenotypic plasticity. Oecologia 113: 118-196.

Cordero RA, Fetcher N, Voltzow J. 2007. Effects of wind on the allometry of two species of plants in an Elfin Cloud Forest. Biotropica 39: 177-185.

Delhaize E, Ryan PR. 1995. Aluminum toxicity and tolerance in plants. Plant Physiology 107: 315-321.

Dick RP, Thomas DR, Halvorson JJ. 1996. Standardized methods, sampling, and sample pretreatment. In: Doran JW, Jones AJ. (eds.) Methods for Assessing Soil Quality. Madison, SSSA Special Publication 49. p. $107-121$

Ellison AM, Buckley HL, Miller TE, Gotelli NJ. 2004. Morphological variation in Sarracenia purpurea (Sarraceniaceae): geographic, environmental, and taxonomic correlates. American Journal of Botany 91: 1930-1935.

EMBRAPA - Empresa Brasileira de Pesquisa Agropecuária. 1997. Manual de Métodos e Análises de Solo. Rio de Janeiro, EMBRAPA.

Fernandes GW, Barbosa NPU, Negreiros D, Paglia AP. 2014. Challenges for the conservation of vanishing megadiverse rupestrian grasslands. Natureza \& Conservação 12: 162-165.

Fontes MAL. 1999. Padrões alométricos em espécies arbóreas pioneiras tropicais. Scientia Forestalis 55: 79-87.

Giulietti AM, Pirani JR, Harley RM. 1997. Espinhaço range region, eastern Brazil. In: Davis SD, Heywood VH, Herrera-MacBryde O, Villa-Lobos J, Hamilton AC. (eds.) Centres of plant diversity: a guide and strategy for their conservation. Cambridge, WWF/IUCN. p. 397-404.

Glassman S. 1987. Revision of the palm genus Syagrus Mart. and another selected genera in the Cocos alliance. Illinois Biological Monographs 56: $1-230$.

Goodland R, Ferri MG. 1979. Ecologia do Cerrado. São Paulo, EDUSP.

Goodland R, Pollard R. 1973. The Brazilian Cerrado vegetation: A fertility gradient. Journal of Ecology 61: 219-224.

Goodman RC, Phillips OL, Torres DDC, et al. 2013. Amazon palm biomass and allometry. Forest Ecology and Management 310: 994-1004.

Jones DL, Kochian LV. 1995. Aluminum inhibition of the inositol 1,4,5-trisphosphate signal transduction pathway in wheat roots: a role in Aluminum Toxicity? The Plant Cell 7: 1913-1922.

Kimura M, Simbolon H. 2002. Allometry and life history of a forest understory palm Pinanga coronata (Arecaceae) on Mount Halimun, West Java. Ecological Research 17: 323-338.

King DA. 1996. Allometry and life history of tropical trees. Journal of Tropical Ecology 12: 25-44.

Kjaer A, Barfod AS, Asmussen CB, Seberg O. 2004. Investigation of genetic and morphological varation in the Sago Palm (Metroxylon sagu; Arecaceae) in Papua New Guinea. Annals of Botany 94: 109-117.

Le Stradic S, Buisson E, Fernandes GW. 2014. Restoration of Neotropical grasslands degraded by quarrying using hay transfer. Applied Vegetation Science 17: 482-492.

Lopes AS. 1984. Solos sob Cerrado: características, propriedades e manejo. Piracicaba, POTAFOS.

Lortie CJ, Aarssen LW. 1996. The specialization hypothesis for phenotypic plasticity in plants. International Journal of Plant Sciences 157: 484-487.

Lüttge U, Duarte HM, Scarano FR, et al. 2007. Physiological ecology of photosynthesis of five sympatric species of Velloziaceae in the rupestrian fields of Serra do Cipó, Minas Gerais, Brazil. Flora 202: 637-646.

MacMahon T. 1973. Size and shape in biology. Science 179: 1201-1204.

Madeira JA, Fernandes GW. 1999. Reproductive phenology o sympatric taxa of Chamaecrista (Leguminosae) in Serra do Cipó, Brazil. Journal of Tropical Ecology 15: 463-479.

Malavolta EC, Kliemann HJ. 1985. Desordens nutricionais do Cerrado. Piracicaba, POTAFOS

Marcato AC, Pirani JR. 2001. Flora da Serra do Cipó, Minas Gerais: Palmae (Arecaceae). Boletim de Botânica da Universidade de São Paulo 19: 45-54.
Marques AR, Garcia QS, Rezende JP, Fernandes GW. 2000. Variations in leaf characteristics of two species of Miconia in the Brazilian Cerrado under different light intensities. Tropical Ecology 41: 47-60.

Miola DTB, Correia HVL, Fernandes GW, Negreiros D. 2010. Efeito do fogo na fenologia de Syagrus glaucescens Glaz. Ex Becc. (Arecaceae). Neotropical Biology and Conservation 5: 146-153.

Miola DTB, Freitas CR, Barbosa M, Fernandes GW. 2011. Modeling the spatial distribution of the endemic and threatened palm shrub Syagrus glaucescens (Arecaceae). Neotropical Biology and Conservation 6: 78-84.

Motta PEF, Curi N, Franzmeier DP. 2002. Relation of soils and geomorphic surfaces in the Brazilian Cerrado. In: Oliveira PS, Marquis RJ. (eds.) The Cerrados of Brazil. New York, Columbia University Press. p. 13-32.

Negreiros D, Fernandes GW, Silveira FAO, Chalub C. 2009. Seedling growth and biomass allocation of endemic and threatened shrubs of rupestrian fields. Acta Oecologica 35: 300-310.

Negreiros D, Le Stradic S, Fernandes GW, Rennó HC. 2014. CSR analysis of plant functional types in highly diverse tropical grasslands of harsh environments. Plant Ecology 215: 379-388.

Niklas KJ. 1993. The scaling of plant height: a comparison among major plant clades and anatomical grades. Annals of Botany 72: 165-172.

Niklas KJ. 1994. Plant allometry: the scaling of form and process. Chicago, The University of Chicago Press.

Niklas KJ. 2004. Plant allometry: is there a grand unifying theory? Biological Reviews 79: 871-889.

Niklas KJ. 2006. Plant Allometry, Leaf Nitrogen and Phosphorus Stoichiometry, and Interspecific Trends in Annual Growth Rates. Annals of Botany 97: 155-163.

Noblick L. 1998. Syagrus glaucescens. The IUCN Red List of Threatened Species. Version 2014.3. <www.iucnredlist.org>. 10 Dec. 2014.

O’Brien ST, Hubbel SP, Spiro P, Condit R, Foster RB. 1995. Diameter, height, crown, and age relationships in eight neotropical tree species. Ecology 76: 1926-1939.

Oliveira-Filho AT, Ratter JA. 2002. Vegetation physiognomies and woody flora of the Cerrado biome. In: Oliveira PS, Marquis RJ. (eds.) The Cerrados of Brazil: ecology and natural history of a Neotropical savanna. New York, Columbia University Press. p. 91-120.

Osunkoya OO, Omar-Ali K, Amit N, Dayan J, Daud D, Sheng TK. 2007. Comparative height-crown allometry and mechanical design in 22 tree species of Kuala Belalong Rainforest, Brunei, Borneo. American Journal of Botany 94: 1951-1962.

Poorter H, Niklas KJ, Reich PB, Oleksyn J, Poot P, Mommer L. 2012. Biomass allocation to leaves, stems and roots: meta-analyses of interspecific variation and environmental control. New Phytologist 193: 30-50.

Rocha-Filho LC, Lomônaco C. 2006. Variações fenotípicas em subpopulações de Davilla elliptica St. Hill (Dilleniaceae) e Byrsonima intermedia A. Juss. (Malpighiaceae) em uma área de transição cerrado-vereda. Acta Botanica Brasilica 20: 719-725.

Rosseto V, Carneiro MS, Ramos FN, Santos FAM. 2013. Ontogeny, allometry and architecture of Psychotria tenuinervis (Rubiaceae). Acta Botanica Brasilica 27: 730-736.

Santos FAM. 2000. Growth and leaf demography of two Cecropia species. Revista Brasileira de Botânica 23: 133-141.

Schatz GE, Williamson GB, Cogswell CM, Stam AC. 1985. Stilt roots and growth of arboreal palms. Biotropica 17: 206-209.

Sposito TC, Santos FAM. 2001. Scaling of stem and crown in eight Cecropia (Cecropiaceae) species of Brazil. American Journal of Botany 88: 939-949.

Via S, Gomulkiewicz R, Jong GD, Scheiner SM, Schlichting CD, Tienderen PHV. 1995. Adaptive phenotypic plasticity: consensus and controversy. Trends in Ecology \& Evolution 10: 212-217.

Weiner J, Fishman L. 1994. Competition and allometry in Kochia scoparia. Annals of Botany 73: 263-271.

Weiner J. 2004. Allocation, plasticity and allometry in plants. Perspectives in Plant Ecology, Evolution and Systematics 6: 207-215. 